\title{
GOVERNMENT REVENUE AND EXPENDITURE NEXUS IN SouTh AFrica
}

\author{
Morekwa Esman Nyamongo, Moses M Sichei and Niek J Schoeman \\ Department of Economics, University of Pretoria
}

\begin{abstract}
This paper investigates the nexus between government expenditure and government revenue in South Africa within the framework of a vector autoregressive (VAR) approach. It uses the Hylleberg et al. (1990) method to test for seasonal unit roots and finds that government revenue and government expenditure have unit roots at all frequencies. The Johansen procedure test results reveal that these variables are cointegrated. It is further established that revenue and expenditure are linked bidirectionally by Granger causality in the long-run, while there is no evidence of Granger causality in the short-run in South Africa.
\end{abstract}

JEL: H2, H24

\section{1}

Introduction

The close relationship between government revenue and government expenditure has attracted considerable interest. As Narayan (2005) argues, this is not surprising given the impact of the revenue-expenditure nexus on budget deficits. Much work has been done on the revenue and expenditure nexus, using diverse methods ranging from traditional to advanced econometric techniques.

In developed countries, Von Furstenburg, Green and Jeong (1986) investigated the nexus between government revenues and expenditure in the US over the period 1955-1981 and found unidirectional Granger causality running from expenditure to revenue. This finding was supported by a study by Anderson, Wallace and Warner (1986). Another study by Manage and Marlow (1986), however, contradicts this, finding causality running from revenue to expenditure, thus supporting the tax-spend hypothesis. In a further twist of this tale, Ram (1988) found evidence of bi-directional Granger causality, which conforms to the fiscal synchronisation hypothesis, and Owoye (1995), using Engle-Granger error correction method for the G-7 countries for the period 1961-1990, found evidence of the fiscal synchronisation hypothesis in Canada, France, Germany, UK and the US. However, in Italy and Japan they found evidence of a tax spending causality. Joulfaian and Mookerjee (1991), investigating 22 OECD countries, found Granger causality from revenue to expenditure in most of the countries except for Canada, Iceland and Japan, and causality running from expenditure to revenue in all countries except for France, Greece and Ireland.

In Latin America, Granger causality was tested by Shah and Baffles (1994), who found evidence in Brazil of unidirectional causality running from revenue to expenditure. However, in Argentina and Mexico they found evidence of bi-directional causality between government expenditure and revenue. In the Middle East, Fasano and Wang (2002) investigated the nexus among the oil-dependent Gulf Cooperation Council countries and found evidence of bidirectional causality for Qatar, Kuwait and Saudi Arabia and unidirectional causality running from revenue to expenditure in Bahrain, the United Arab Emirates and Oman. In Africa, 
Carneiro, Faira and Barry (2004) researched government revenue and expenditure causality and cointegration in Guinea-Bissau and found evidence of temporal causality and a long-run relationship between government revenue and expenditure.

Narayan and Narayan (2006) investigated the nexus between government revenue and expenditure in 12 developing countries using annual data. They looked for evidence of causality between government revenue and government expenditure within a multivariate framework using the Toda and Yamamoto (1995) test of Granger causality. The main findings were that the tax-spend hypothesis is supported by data from Mauritius, El Salvador, Haiti, Chile and Venezuela. For Haiti, there is evidence of the spend-tax hypothesis, while for Peru, South Africa, Guatemala, Uruguay and Ecuador there is evidence of fiscal neutrality. In another study, Chang, Liu and Caudill (2002) used cointegration and vector autoregression to test the revenue-expenditure nexus in 10 countries during the period 1951-1996. They found that the spend-tax hypothesis is supported by data from South Africa and Australia, the tax-spend hypothesis by data from Japan, South Korea, Taiwan, UK and the US; the fiscal synchronisation hypothesis by data from Canada; and fiscal neutrality by data from New Zealand and Thailand.

In Asia, Narayan (2005) tested the nexus between government revenue and expenditure in nine Asian countries. The study used the bounds testing approach to cointegration and causality. It was found that in three out of the nine countries government revenue and expenditure are cointegrated. The findings in this study on the direction of causality were mixed; for Indonesia, Singapore, Sri Lanka in the short term and Nepal both in the longand short-term, data supports the tax-spend hypothesis. For Indonesia and Sri Lanka a spend-tax trend was found in the long term but in all other countries evidence of neutrality was found.

A number of studies have used cointegration analysis and error correction techniques to test for the nexus between government revenue and expenditure. In China, for example, $\mathrm{Li}$
(2001) found bi-directional causality between government revenue and expenditure. In the US, Baghestani and McNown (1994) used a cointegration approach and found evidence of cointegration but not of causality of any kind during the period 1955-1989, while Jones and Joulfaian (1991) used Engle-Granger error correction for the period 1792-1860 and found evidence in support of the spend-tax hypothesis.

This paper seeks to add to existing knowledge about the government revenue-expenditure relationship in South Africa in a number of ways. Firstly, monthly data rather than annual data is used, unlike in most other studies; for example, Narayan and Narayan (2006) and Chung et al. (2002) use annual data for the periods 1960-2000 and 1951-1996 respectively. Secondly, this study performs unit roots using a modified version of the method developed by Hylleberg, Engle, Granger and Yoo (1990) ${ }^{1}$, to take into account seasonal unit roots at monthly frequency. Thirdly, this analysis transcends the standard VAR by using the Vector Error Correction Model (VECM) approach to test the revenueexpenditure nexus in South Africa.

The rest of the paper is organised as follows: section 2 discusses the theoretical issues surrounding the revenue-expenditure nexus and outlines a method to be used to test for unit roots denominated in monthly frequency. It also discusses cointegration and Granger causality tests. Section 3 presents the unit root results using the HEGY method and cointegration between government expenditure and revenue. It also presents Granger causality results. Section 4 discusses some conclusions and policy recommendations.

\section{2}

\section{Theoretical framework and research method}

A study of the literature reveals four schools of thought regarding the revenue-expenditure nexus, namely the tax-spend, spend-tax, fiscal synchronisation and fiscal neutrality schools.

According to the tax-spend theory, rising taxes will simply cause the government to increase 
expenditure (see Friedman, 1978). As argued by Friedman (1982), budget deficit cannot be reduced by simply raising taxes as this only results in more spending, leaving the deficit at the highest level acceptable by the public.

The spend-tax school argues the opposite, that rising expenditure causes a rise in revenue. This is motivated by the seminal work of Peacock and Wiseman $(1961,1979)$ who argue that increases in government spending in crisis situations leads to permanent changes in expenditure rather than revenue.

The third theory, the fiscal synchronisation school, argues that governments may change expenditure and taxes simultaneously. This was proposed by Musgrave (1966) and Meltzer and Richard (1981). This theory assumes bi-directional causality between government expenditure and government revenue. To prove the fiscal synchronisation hypothesis, Barro (1979) developed a tax-smoothing model based on Ricardian equivalence, stating that deficitfinanced government expenditure today results in future tax increases.

The fourth school, the fiscal neutrality school, argues that decisions to spend and raise revenue are taken independently (Baghestani \& McNown, 1994).

\subsection{Seasonal unit root tests on monthly data}

Prior to investigating expenditure-revenue causality in South Africa, it is imperative to determine the order of integration of these variables. This is necessary because, as argued in the literature, if the variables are stationary, Granger causality is performed directly via a standard VAR. Also, if unit roots exist then estimation of a VECM is necessary.

Several methods are proposed in the econometric literature for testing unit roots in the context of seasonal time series. These include methods developed by Hylleberg et al. (1990), Canova and Hansen (1995), Caner (1998) and Shin and So (2000). The HEGY method is used in this study, as it allows for simultaneous testing for a unit root at frequency zero (non seasonal unit root) when unit roots may be present at some or all of the seasonal frequencies. We apply the method to monthly data in a manner consistent with the approaches of Beaulieu and Miron (1993) and Ghysels, Lee and Noh (1994). To test for unit roots at various frequencies, equation 1 is estimated using the ordinary least squares method.

$$
\begin{aligned}
& y_{8, t}=\sum_{s=1}^{11} \delta_{s} D_{s, t}+\beta T+\pi_{2} y_{2, t-1}+\pi_{3} y_{3, t-1}+\pi_{4} y_{3, t-2}+\pi_{5} y_{4, t-1}+\pi_{6} y_{4, t-2} \\
& +\pi_{7} y_{5, t-1}+\pi_{8} y_{5, t-2}+\pi_{9} y_{6, t-1}+\pi_{10} y_{6, t-2}+\pi_{11} y_{7, t-1}+\pi_{12} y_{7, t-2}+\sum_{i=1}^{p} \varphi_{i} y_{8, t-i}+\varepsilon_{t}
\end{aligned}
$$

The estimated coefficients of this model facilitate testing for seasonal unit roots by examining the significance of the parameter $\pi_{i}(i$ $=1,2,3 \ldots 12$ ), where $\mathrm{T}$ is the deterministic time trend, $D_{s, t}$ is the orthogonolised seasonal dummy variable and $\varepsilon_{t}$ is the error term. A number of transformations shown in equations 1.1 through 1.8 in Appendix 1 are performed on the variables of this model. Equation 1 is the augmented Dickey-Fuller auxiliary regression. In order to render the residuals from this equation, white noise, lagged $y_{8, t}$ is incorporated on the righthand side. To remove seasonal unit roots and preserve the long-run or zero frequency unit root, $y_{1, t}$ transformation (Equation 1.1 in the Appendix) is performed. Other transformations include $y_{2,}$, which preserves the frequency, $\pi$, corresponding to a semi-annual period; $y_{3, t}$, which preserves the frequency, $(1 / 2) \pi[(3 / 2) \pi]$, that corresponds to quarterly data frequency; $y_{4, t}, y_{5, t}, y_{6, t}$ and $y_{7, t}$ which preserve the frequencies $(5 / 6) \pi[(7 / 6) \pi] ;(1 / 6) \pi[(11 / 6) \pi] ;(2 / 3) \pi[(4 / 3) \pi]$; and $(1 / 3) \pi[(5 / 3) \pi]$ respectively.

The null hypothesis of a non-stationary component at the frequencies $(1 / 2) \pi[(3 / 2) \pi]$, $(5 / 6) \pi[(7 / 6) \pi],(1 / 6) \pi[(11 / 6) \pi],(2 / 3) \pi[(4 / 3) \pi]$ and $(1 / 3) \pi[(5 / 3) \pi]$ are respectively based on the Fvalues which have a non-standard distribution. The joint F-tests for $\pi_{3}=\pi_{4}=0, \pi_{5}=\pi_{6}=0, \pi_{7}=$ $\pi_{8}=0, \pi_{9}=\pi_{10}=0$, and $\pi_{11}=\pi_{12}=0$ are denoted as $\mathrm{F}\left(\pi_{3}, \pi_{4}\right), \mathrm{F}\left(\pi_{5}, \pi_{6}\right), \mathrm{F}\left(\pi_{7}, \pi_{8}\right), \mathrm{F}\left(\pi_{9}, \pi_{10}\right)$ and $\mathrm{F}\left(\pi_{11}, \pi_{12}\right)$, respectively. In this regard, if $\pi_{3}=$ 
$\pi_{4}=0$, the possibility of seasonal unit root at frequency $(1 / 2) \pi[(3 / 2) \pi]$ is not rejected; if $\pi_{5}=$ $\pi_{6}=0$, the possibility of seasonal unit root at frequency $(5 / 6) \pi[(7 / 6) \pi]$ is not rejected; if $\pi_{7}=$ $\pi_{8}=0$, the possibility of seasonal unit root at frequency $(1 / 6) \pi[(11 / 6) \pi]$ is not rejected; if $\pi_{9}=$ $\pi_{10}=0$, the possibility of seasonal unit root at frequency $(2 / 3) \pi[(4 / 3) \pi]$ is not rejected; and if $\pi_{11}=\pi_{12}=0$, the possibility of seasonal unit root at frequency $(1 / 3) \pi[(5 / 3) \pi]$ is not rejected. When using the F-values, the null hypothesis of unit root at each frequency is rejected if the F-value is too large compared to the critical values ${ }^{2}$.

\subsection{Cointegration analysis}

A number of methods are suggested in the literature to test causal links between government expenditure and government revenue. In this study, the cointegration approach (Johansen, $1985 ; 1988)$ is used. In this approach, vector $Z_{t}$ is defined where $\mathrm{Z}_{t}=\left(G R_{t}, G E_{t}^{\prime}\right)^{\prime}, \mathrm{GR}_{t}$ is the dependent variable and $\mathrm{GE}_{t}$ is the independent variable (or otherwise). If the variables in $\mathrm{Z}_{t}$ are non-stationary, then by Granger representation theorem, parameters can be reset as a vector error correction model (VECM) as follows:

$$
\begin{aligned}
& \Delta G R_{t}=\alpha_{0}+\gamma_{G R} G R_{t-1}+\varpi_{G E} G E_{t-1}+\sum_{i=1}^{p} \pi_{i} \Delta G R_{t-i}+\sum_{j=0}^{p} \vartheta_{j}^{\prime} \Delta G E_{t-j}+\varepsilon_{t} \\
& \text { or } \\
& \Delta G E_{t}=\alpha_{0}+\gamma_{G E} G E_{t-1}+\varpi_{G R} G R_{t-1}+\sum_{i=1}^{p} \pi_{i} \Delta G E_{t-i}+\sum_{j=0}^{p} \vartheta_{j}^{\prime} \Delta G R_{t-j}+\varepsilon_{t}
\end{aligned}
$$

where $\Delta$ is the difference operator and GE and GR are the logarithms of government expenditure and government revenue, respectively.

\subsection{Granger causality}

Thus evidence of a cointegrating relationship between government revenue and government expenditure is crucial for the correct specification of a model to test for Granger causality. If the absence of cointegration among the variables is established, then a VAR model is estimated. However, if the variables are non-stationary and cointegrated, a VECM is specified and estimated as:

$\Delta G R_{t}=\beta_{0}+\pi_{11}^{p}(L) \Delta G R_{t}+\pi_{12}^{q}(L) \Delta G E_{t-1}+\eta E C T_{t-1}+\varepsilon_{1 t}$

and

$\Delta G E_{t}=\beta_{1}+\pi_{21}^{p}(L) \Delta G E_{t}+\pi_{22}^{q}(L) \Delta G R_{t-1}+\vartheta E C T_{t-1}+\varepsilon_{2 t}$

where $\pi_{i j}^{p}(L)=\sum_{n=1}^{p_{i j}} \pi_{i j n} L^{1}$ and $\pi_{i j}^{p}(L)=\sum_{n=1}^{q_{i j}} \pi_{i j n} L^{1}$. $\mathrm{L}$ is the lag operator while all other variables are as previously defined. Using equations $3 \mathrm{a}$ and $3 b$, long- and short-run Granger causality can be tested. Granger causality in the longrun is tested by checking the significance of the parameter estimates of the error correction term $\left(\mathrm{ECT}_{\mathrm{t}-1}\right)$ where the null hypothesis to test is stated as $\mathrm{H}_{0}: \eta=0$ (i.e. government expenditure does not Granger-cause government revenue in the long-run) in equation $3 \mathrm{a}$ and $\mathrm{H}_{0}: \vartheta=0$ (i.e. government revenue does not Grangercause government expenditure in the longrun) in equation $3 \mathrm{~b}$. On the other hand,
Granger causality in the short-term is tested via restrictions (joint insignificance) of the parameters $\pi_{12}^{q}$ and $\pi_{22}^{q}$ in equations $3 a$ and $3 \mathrm{~b}$, respectively. This is performed using the Wald parameter restrictions test, in which the null hypothesis is $\mathrm{H}_{0}: \pi_{12}^{q}=0$ (i.e. government expenditure does not Granger-cause government revenue in the short-run) in equation $3 \mathrm{a}$ and $\mathrm{H}_{0}: \pi_{22}^{q}=0$ (i.e. government revenue does not Granger-cause government expenditure in the short-run) in equation $3 b$. 
3

\section{Empirical results}

\subsection{Data description and initial analysis}

This study uses monthly data to test the government revenue-expenditure nexus in South Africa. The data is obtained from the South African Reserve Bank; website www. reservebank.co.za, for the period October 1994 to June 2004. The data has not been seasonally adjusted.
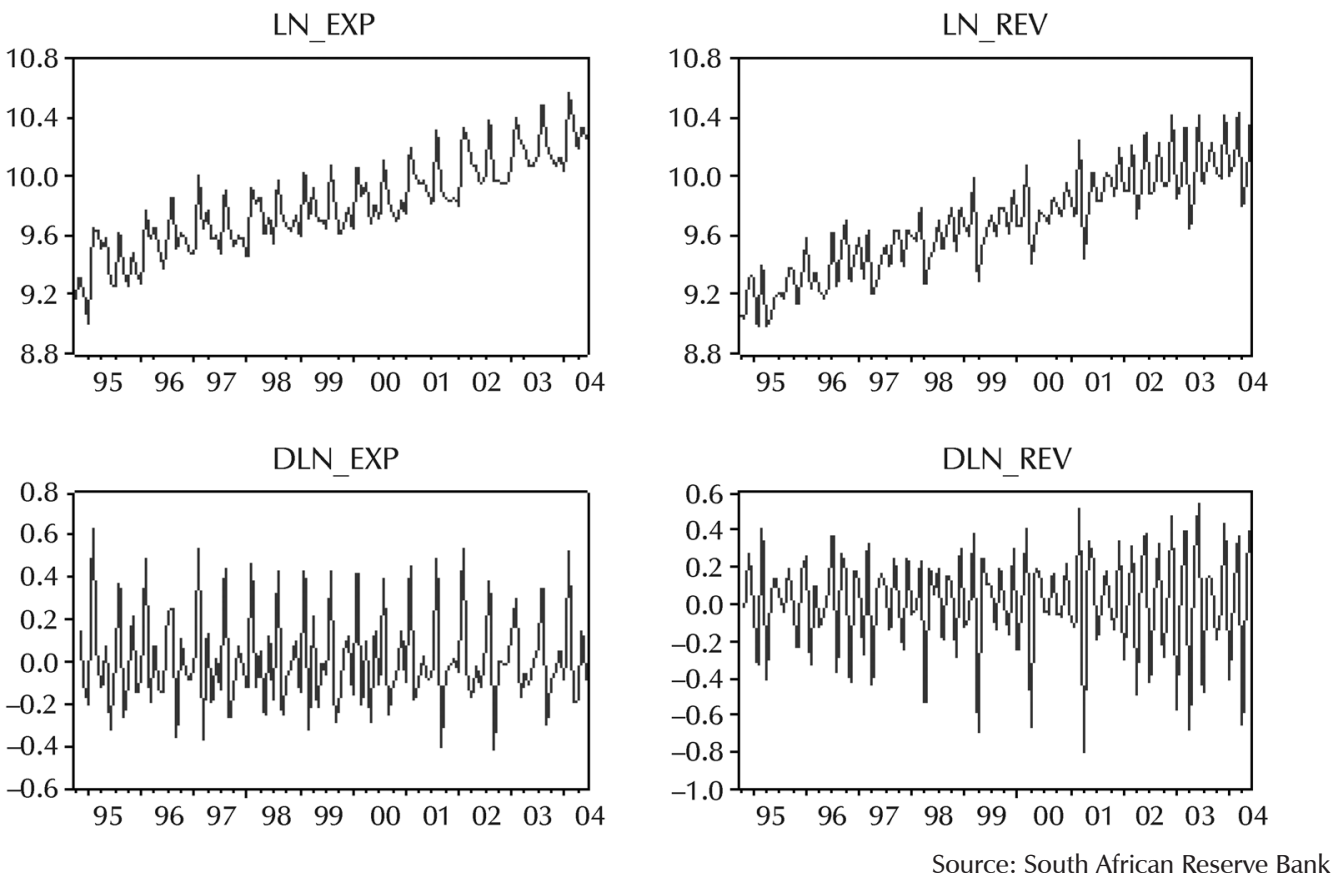

Figure 1

Trends of government expenditure and government revenue in South Africa 1994-2004

Figure 1 shows a graphical representation of the logarithm of government revenue (LN_REV) against government expenditure (LN_EXP) in levels as well as first differences. From the figure it appears that government revenue and expenditure are not stationary. Differencing the variables results in the graphs DLN_EXP and DLN_REV which suggest that these variables are integrated in the first order. However, due to the seasonal complications found in time series data of high frequency, formal tests of unit root were conducted, as explained in the next section.

\subsection{Unit root results}

The results for conventional Augemented Dickey Fuller (ADF) (Dickey \& Fuller, 1979; 1981), Phillips-Perron (PP) (Phillips \& Perron, 1988) and Kwiatkowski- (KPSS) (Kwiatkowski, Phillips, Schmidt and Shin, 1992) tests for unit $\operatorname{root}^{3}$ and the HEGY method are reported in Table 1 below. 
Table 1

Test for seasonal unit roots for government expenditure

\begin{tabular}{|l|c|c|c|c|}
\hline & Intercept & $\begin{array}{c}\text { Intercept and } \\
\text { seasonal dummies }\end{array}$ & $\begin{array}{c}\text { Intercept and } \\
\text { trend }\end{array}$ & $\begin{array}{c}\text { Intercept, } \\
\text { seasonal dummies } \\
\text { and trend }\end{array}$ \\
\hline$t\left(\pi_{1}\right)$ & 2.434202 & 2.439681 & -1.927677 & -1.169930 \\
\hline$t\left(\pi_{2}\right)$ & -0.400737 & -1.313065 & -0.721005 & -1.424828 \\
\hline$F\left(\pi_{3}, \pi_{4}\right)$ & 0.538541 & 2.318863 & 0.167818 & 2.338509 \\
\hline$F\left(\pi_{5}, \pi_{6}\right)$ & 0.307488 & 0.424772 & 0.147318 & 0.161822 \\
\hline$F\left(\pi_{7}, \pi_{8}\right)$ & 0.275262 & 0.724540 & 0.195340 & 0.332690 \\
\hline$F\left(\pi_{9}, \pi_{10}\right)$ & 0.629254 & 2.687057 & 1.436506 & 2.397425 \\
\hline$F\left(\pi_{11}, \pi_{12}\right)$ & 1.107888 & 0.994433 & 1.416435 & 1.019352 \\
\hline$F\left(\pi_{2} \ldots \ldots . \pi_{12}\right)$ & 0.686406 & 1.783679 & 0.649698 & 1.629416 \\
\hline$F\left(\pi_{1} \ldots \ldots . \pi_{12}\right)$ & 0.676260 & 2.279471 & 0.957883 & 1.749941 \\
\hline
\end{tabular}

Table 1 shows the unit root results of government expenditure; critical values ${ }^{4}$ are reported in the endnote. The presence of a unit root at a particular frequency is established if the relevant test statistic is less than the corresponding tabulated critical value given in Beaulieu and Mirron (1993). The seasonal unit roots for government expenditure at monthly frequencies are reported in Table 1 . From the table it is evident that the model with intercept only shows that the null hypothesis of unit roots at annual and semi-annual frequencies are accepted at 5 per cent level. Based on the F-value, on the other hand, the null hypothesis of unit root at quarterly and all other higher frequencies are accepted at 5 per cent level. This, therefore, suggests that government expenditure is non-stationary at annual to monthly frequency. The same results are also found when testing for unit roots using other model specifications listed in columns 3 through 6 , which leads to the conclusion that government expenditure is non-stationary.

Table 2 shows the results of the unit root tests for government revenue. It can be observed that the null hypothesis of seasonal unit roots at annual frequency is accepted at 5 per cent level of testing.

Table 2

Test for seasonal unit roots for government revenue

\begin{tabular}{|l|c|c|c|c|}
\hline & Intercept & $\begin{array}{c}\text { Intercept and } \\
\text { seasonal dummies }\end{array}$ & $\begin{array}{c}\text { Intercept and } \\
\text { trend }\end{array}$ & $\begin{array}{c}\text { Intercept, } \\
\text { seasonal dummies } \\
\text { and trend }\end{array}$ \\
\hline$t\left(\pi_{1}\right)$ & 0.007052 & -0.487238 & -0.760089 & -2.044336 \\
\hline$t\left(\pi_{2}\right)$ & 0.043711 & -1.304305 & 0.170368 & -1.301686 \\
\hline$F\left(\pi_{3}, \pi_{4}\right)$ & 4.737344 & 3.020342 & 3.255362 & 2.279778 \\
\hline$F\left(\pi_{5}, \pi_{6}\right)$ & 4.823091 & 2.6788675 & 3.817982 & 3.119904 \\
\hline$F\left(\pi_{7}, \pi_{8}\right)$ & 4.844743 & 3.824544 & 3.914884 & 4.432018 \\
\hline$F\left(\pi_{9}, \pi_{10}\right)$ & 0.008397 & 4.238258 & 0.061539 & 4.399489 \\
\hline$F\left(\pi_{11}, \pi_{12}\right)$ & 1.091147 & 1.172266 & 0.830559 & 0.854623 \\
\hline$F\left(\pi_{2} \ldots \ldots . \pi_{12}\right)$ & 1.69040 & 2.596049 & 1.266843 & 2.890457 \\
\hline$F\left(\pi_{1} \ldots \ldots . \pi_{12}\right)$ & 1.593439 & 2.426349 & 1.602339 & 2.905330 \\
\hline
\end{tabular}


The seasonal unit root at semi-annual intervals is not rejected at 5 per cent level of testing. The null hypothesis of unit roots at quarterly frequency has an F-statistic of 4.74, which is lower than the tabulated critical value of 6.35 ; thus the unit root is accepted at 5 per cent level. Other frequencies also have F-values lower than the critical values tabulated at 6.34, 6.30, 6.37, and 6.31, which, therefore, accept the null hypothesis of unit roots at all frequencies. The same results are found with other specifications leading to the conclusion that government revenue is non-stationary at annual and higher frequency.

\subsection{Cointegration results}

As a prerequisite to cointegration within a vector autoregressive framework, a number of tests were conducted. Firstly, lag selection was performed using lag selection criteria; most of the tests admit a lag length of 3. Tests on the stability of the VAR showed that our VAR is stable. The cointegration results based on Johansen procedure are reported in Table 3.

Table 3

Cointegration test results

\begin{tabular}{|c|c|c|c|c|}
\hline \multicolumn{5}{|l|}{ Panel A: Rank test (trace) } \\
\hline $\begin{array}{c}\text { Hypothesised } \\
\text { no. of CE(s) }\end{array}$ & Eigenvalue & $\begin{array}{c}\text { Trace } \\
\text { statistic }\end{array}$ & $\begin{array}{c}\mathbf{0 . 0 5} \\
\text { Critical value }\end{array}$ & Prob. \\
\hline$\lambda=0$ & 0.187527 & 23.93173 & 20.26184 & 0.0149 \\
\hline$\lambda \leq 1$ & 0.024373 & 2.541508 & 9.164546 & 0.6693 \\
\hline Panel B: Rank test (maximum Eigenvalue) & & & \\
\hline$\lambda=0$ & 0.187527 & 21.39022 & 15.89210 & 0.0061 \\
\hline$\lambda \leq 1$ & 0.024373 & 2.541508 & 9.164546 & 0.6693 \\
\hline
\end{tabular}

As reported in Table 3, the trace test for cointegration shows one cointegrating relationship at 5 per cent level of testing. The same is true for the maximum Eigenvalue test. There is, therefore, a long-run relationship between government expenditure and government revenue in South Africa during the period under study. Existence of cointegration between these variables, as demonstrated by Granger (1988), is evidence of causality at least in one direction. The resulting cointegration graph is presented in Figure 2.

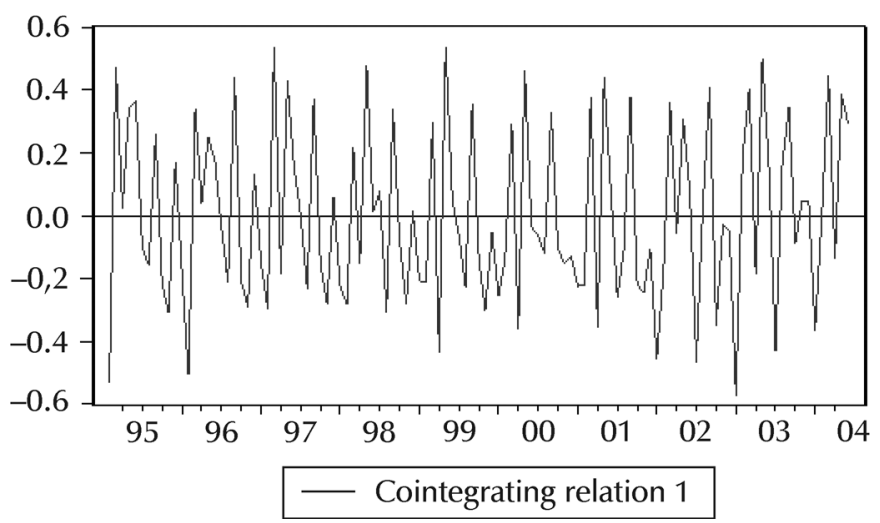

Figure 2

Cointegrating vector 
The long-run models of government revenue and expenditure are as follows:

$$
\text { Ln_exp }=-0.002 \text { Trend }+1.083 \text { Ln_rev }
$$

$$
(-0.932) \quad(4.191)
$$

and

$$
\begin{gathered}
\text { Ln_rev }= \\
(1.325)
\end{gathered}
$$

In the long-run government expenditure model, the time trend is negative and not significant at the conventional levels of testing. The estimated coefficient of government revenue is positive and significant at 1 per cent level of testing. This, therefore, suggests that a 1 per cent change in revenue leads to a 1.083 per cent change in government expenditure. On the other hand, the long-run government revenue model shows that the estimated coefficient of the time trend is positive but not significant at the conventional levels of testing, while the coefficient of government expenditure is positive and significant at the 1 per cent level, which suggests that a 1 per cent change in government expenditure leads to a 0.923 per cent change in government revenue. In terms of fiscal policy, these results suggest that any increase in revenue will lead to a more than proportionate increase in expenditure such that if the government plans to have a balanced budget, any unexpected increase in revenue will simply occasion higher spending, which will eventually lead to higher fiscal deficits. The same is true where a change in government expenditure leads to a less than proportionate change in government revenue, which implies that government revenue will not respond proportionately and may result in

\begin{tabular}{|c|c|c|}
\hline & D(LN_EXP) & D(LN_REV) \\
\hline $\operatorname{ECM}(-1)$ & $\begin{array}{l}-0.675^{* * *} \\
(-4.380)\end{array}$ & $\begin{array}{l}-0.529^{* * *} \\
(-2.667)\end{array}$ \\
\hline $\mathrm{D}\left(\operatorname{Ln} \_\exp (-1)\right)$ & $\begin{array}{l}-0.324^{* *} \\
(-2.296)\end{array}$ & $\begin{array}{l}-0.399 * * \\
(-2.383)\end{array}$ \\
\hline $\mathrm{D}\left(\mathrm{Ln} \_\exp (-2)\right.$ & $\begin{array}{c}-0.191 \\
(-1.488)\end{array}$ & $\begin{array}{l}-0.376^{* *} \\
(-2.466)\end{array}$ \\
\hline $\mathrm{D}\left(\mathrm{Ln} \_\exp (-3)\right.$ & $\begin{array}{c}-0.001 \\
(-0.014)\end{array}$ & $\begin{array}{l}-0.052 \\
(-0.441)\end{array}$ \\
\hline $\mathrm{D}\left(\operatorname{Ln} \_r e v(-1)\right)$ & $\begin{array}{l}-0.499 * * * \\
(-3.023)\end{array}$ & $\begin{array}{l}-0.655^{* * *} \\
(-3.337)\end{array}$ \\
\hline $\mathrm{D}\left(\operatorname{Ln} \_r e v(-2)\right)$ & $\begin{array}{l}-0.286^{* *} \\
-2.168\end{array}$ & $\begin{array}{l}-0.668^{* * *} \\
-4.267\end{array}$ \\
\hline $\mathrm{D}\left(\operatorname{Ln} \_r e v(-3)\right)$ & $\begin{array}{l}-0.029 \\
(-0.320)\end{array}$ & $\begin{array}{l}-0.070 \\
(-0.648)\end{array}$ \\
\hline C & $\begin{array}{l}0.018^{* *} \\
(2.345)\end{array}$ & $\begin{array}{l}0.031^{* * *} \\
(3.337)\end{array}$ \\
\hline D_1 & $\begin{array}{c}-0.082 \\
(-1.517)\end{array}$ & $\begin{array}{c}-0.068 \\
(-1.055)\end{array}$ \\
\hline D_2 & $\begin{array}{l}0.390^{* * *} \\
(6.889)\end{array}$ & $\begin{array}{l}-0.067 \\
(-0.990)\end{array}$ \\
\hline D_3 & $\begin{array}{l}0.201^{* * *} \\
(2.882)\end{array}$ & $\begin{array}{c}0.046 \\
(0.560)\end{array}$ \\
\hline
\end{tabular}
increasing fiscal deficits.

Table 4

Error correction models of government expenditure and government revenue 


\begin{tabular}{|c|c|c|}
\hline D_4 & 0.120 & $-0.346^{* * *}$ \\
& $(1.467)$ & $(-3.561)$ \\
\hline D_5 & 0.042 & $-0.347^{* * *}$ \\
& $(0.540)$ & $(-3.721)$ \\
\hline D_6 & 0.023 & $-0.248^{* * *}$ \\
& 0.425 & -3.881 \\
\hline D_7 & 0.047 & 0.044 \\
& 0.791 & 0.632 \\
\hline D_8 & $0.409 * * *$ & -0.065 \\
& $(7.516)$ & $(-1.008)$ \\
\hline D_9 & 0.083 & -0.025 \\
& $(1.223)$ & $(-0.315)$ \\
\hline D_10 & -0.058 & 0.016 \\
& $(-0.794)$ & $(0.190)$ \\
\hline D_11 & -0.086 & -0.226 \\
& $(-1.278)$ & $(-2.832)$ \\
\hline R-squared & 0.92 & 0.92 \\
\hline Adj R-squared & 0.90 & 0.91 \\
\hline Durbin-Watson stat & 1.987 & 1.919 \\
\hline
\end{tabular}

$\mathrm{t}$-values in parenthesis

Table 4 reports estimation results based on equations $3 \mathrm{a}$ and $3 \mathrm{~b}$. The results show that the error correction term in the government expenditure equation is significant at 1 per cent level of significance. This result suggests that any deviation of government expenditure from its equilibrium path will be restored at a rate of 67.5 per cent per month. On the other hand, the estimated error correction term is significant at 1 per cent in the government revenue equation, indicating that any deviation of revenue from its equilibrium path will require adjustment at a rate of 52.9 per cent per month. All these results, therefore, indicate Granger causality of a bi-directional nature in the long-run in South Africa. This result supports the fiscal synchronisation hypothesis, and contradicts Narayan and Narayan (2006), who found evidence of fiscal neutrality, and Chang et al. (2002), who found evidence of the spend-tax hypothesis in South Africa.

In light of these results, Granger causality in the short-term must be tested for via the Wald coefficient restrictions which are shown in the Table 5 .

Table 5

Short-run Granger causality tests

\begin{tabular}{|l|c|c|}
\hline & x2(3) & Prob. \\
\hline Government revenue equation & 9.399 & 0.024 \\
\hline $\mathrm{D}\left(\mathrm{Ln} \_\exp (-1)=\mathrm{D}\left(\mathrm{Ln} \_\exp (-2)=\mathrm{D}\left(\operatorname{In} \_\exp (-3)=0\right.\right.\right.$ & 16.193 & 0.001 \\
\hline Government expenditure equation & $\mathrm{D}$ \\
\hline $\mathrm{D}\left(\mathrm{Ln}\right.$ _rev $(-1)=\mathrm{D}\left(\mathrm{Ln}\right.$ _rev(-2) $=\mathrm{D}\left(\ln \_r e v(-3)=0\right.$ &
\end{tabular}


From Table 5 it is evident that the null hypothesis that the estimated coefficients of government expenditure are jointly equal to zero is accepted at 5 per cent level of significance, which suggests that there is no Granger causality running from government expenditure to government revenue. On the other hand, the null hypothesis of the joint insignificance (jointly equal to zero) of the coefficients of government revenue in the government expenditure equation is also accepted at 1 per cent level. These findings, therefore, indicate that in the short-term there is no Granger causality of any nature. This finding supports the fiscal neutrality hypothesis, and agrees with Narayan and Narayan (2006), who used annual data and found evidence of fiscal neutrality in South Africa during the period 1960-2000. In the short-term, our findings are
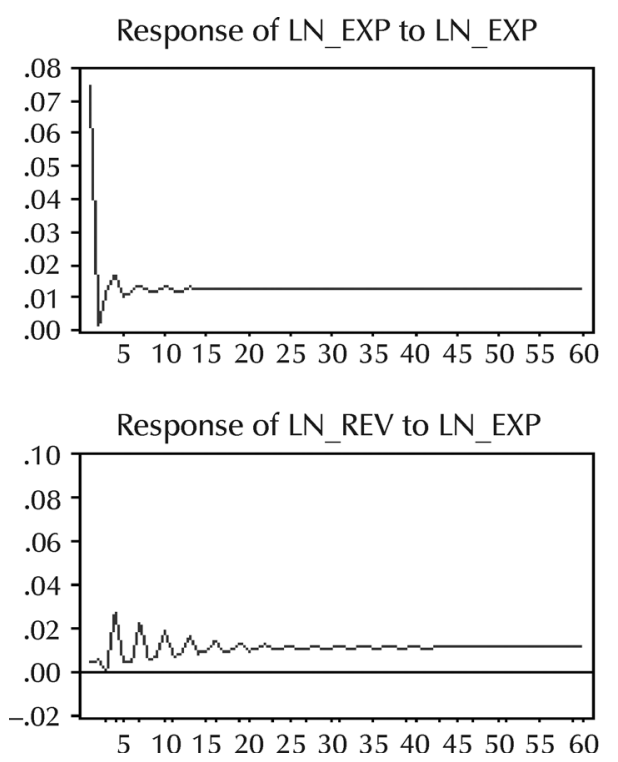

plausible because expenditure and revenue decisions are taken independently, since daily, weekly and monthly expenditure decisions are made by various government departments in conformity with the existing law while revenue targets are set by the National Treasury.

\subsection{Impulse responses}

This section explores what happens to government revenue and expenditure in the case of a temporary shock. Through the dynamic (lag) structure of the VAR, the impulse response function traces the effect of a once-off shock to one of the innovations on current and future values of the endogenous variables. This means that it is possible to identify the pass-through effects of shocks on variables. Figure 3 reports the results of impulse responses.
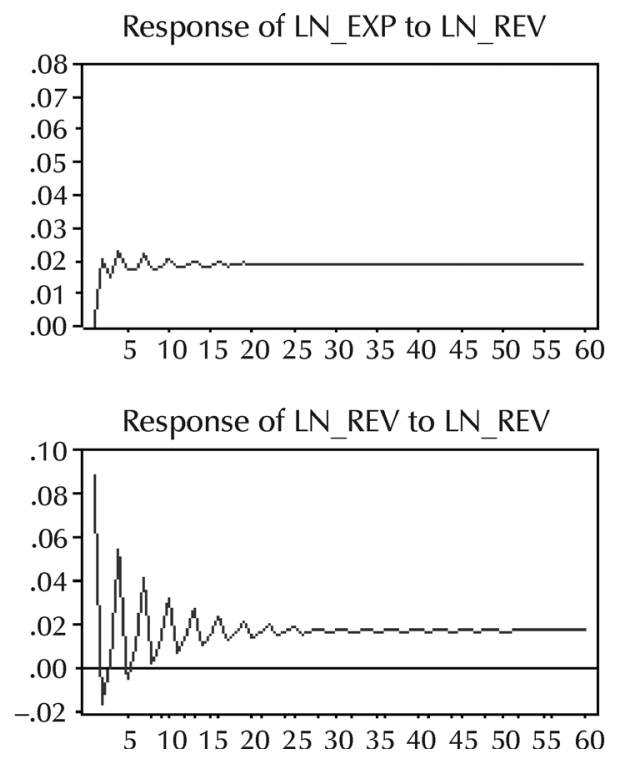

Figure 3

Impulse response representation

It can be observed from the results that firstly, a shock in government expenditure causes a permanent positive effect on expenditure over the 60 months horizon. Secondly, a shock in government revenue also causes a permanent effect on government expenditure. Thirdly, a shock in government expenditure causes government revenue to rise permanently over the 60 months horizon. Finally, a positive innovation of one standard deviation of government revenue also causes a permanent effect on revenue.

4

\section{Conclusion and recommendations}

This paper investigates the question of government expenditure and government revenue in South Africa within the framework of a VAR approach. A modified HEGY method 
was used to test for seasonal unit roots at monthly intervals. It was found that government revenue and expenditure have unit roots at all frequencies. Further evidence shows that government revenue and expenditure are cointegrated, which implies that in the longrun these principal components of fiscal policy are linked. In view of this, a VECM was used to test for Granger causality both in the long and short term. The estimation results show that in the long run, there is evidence of bidirectional Granger causality, which supports the fiscal synchronisation hypothesis. However, there is no evidence of Granger causality between government revenue and government expenditure in the short term, which supports the fiscal neutrality hypothesis.

These findings have important policy implications in both the short and long term. Firstly, in the short term, rejection of the fiscal synchronisation hypothesis confirms that expenditure decisions are made in isolation from revenue decisions. This suggests great risk of budget deficits should government expenditure explode relative to government revenue on a month-to-month basis. Secondly, evidence of fiscal synchronisation in the long term implies that government expenditure and government revenue decisions are not made in isolation. In other words, the fiscal authority is in full control of the principal instruments of fiscal policy such that at any time, should there be a rapid growth of government expenditure relative to government revenue, the budget deficit will not spiral out of control.

\section{Endnotes}

1 This method is referred to as the HEGY from the names of the authors, S. Hylleberg, R.F Engle, C.W.J Granger and B.S. Yoo.

2 A summary of the null hypotheses and alternative hypotheses are presented in Table A1 in the appendix.

3 The results of the unit root tests based on these methods show that government expenditure and government revenue are integrated of order 1. To conserve space these results are not reported, however, they are available on request from the authors.
4 - A model with a constant: t- statistics of $\mathrm{H}_{0}: \pi_{1}=0$ and $\mathrm{H}_{0}: \pi_{2}=0$ are -2.80 and -1.89 respectively. F-statistics of $\mathrm{H}_{0}: \pi_{k}=\pi_{k-1}=0$ is 3.01 .

- A model with a constant and seasonal dummies: $\mathrm{t}$ - statistics of $\mathrm{H}_{0}: \pi_{1}=0$ and $\mathrm{H}_{0}: \pi_{2}=0$ are -3.28 and -2.75 respectively. F-statistics of $\mathrm{H}_{0}: \pi_{k}=$ $\pi_{k-1}=0$ is 6.23 .

- A model with a constant and time trend: t- statistics of $\mathrm{H}_{0}: \pi_{1}=0$ and $\mathrm{H}_{0}: \pi_{2}=0$ are -3.32 and -1.88 respectively. F-statistics of $\mathrm{H}_{0}: \pi_{k}=$ $\pi_{k-1}=0$ is 2.97 .

- A model with a constant, seasonal dummies and time trend: $\mathrm{t}$ - statistics of $\mathrm{H}_{0}: \pi_{1}=0$ and $\mathrm{H}_{0}: \pi_{2}=0$ are -3.28 and -2.75 respectively. F-statistics of $\mathrm{H}_{0}: \pi_{k}=\pi_{k-1}=0$ is 6.23 .

\section{References}

1 ANDERSON, W.; WALLACE, M.S. \& WARNER, J.T. (1986) "Government spending and taxation. What causes what?", Southern Economic Journal, 52.

2 BAGHESTANI, H., \& MCNOWN, R. (1994) "Do revenue or expenditure respond to budgetary disequilibia?", Southern Economic Journal, 52.

3 BARRO, R.J. (1979) "On the determination of public debt”, Journal of Political Economy, 81.

4 BEAULIEU, J.J \& MIRON, J.A. (1993) "Seasonal unit root in aggregate U.S data", Journal of Econometrics, 55: 305-328.

5 CANER, M. (1998) "A local optimal seasonal unit root", Journal of Business and Economics Statistics, 16: 349-359.

6 CANOVA, F. \& HANSEN, B.E. (1995) "Are seasonal patterns constant over time: A test for seasonal stability", Journal of Business and Economics Statistics, 13: 237-252.

7 CARNEIRO, F.G.; FARIA, J.R. \& BARRY, B.S. (2004) "Government revenues and expenditure in Guinea-Bissau”, Africa Region Working Paper, No, 65.

8 CHANG, T.; LIU, W.R., \& CAUDILL, S.B. (2002) "Tax-and-spend, spend-and-tax, or fiscal synchronisation: new evidence from ten countries", Applied Economics, 34: 1553-1561.

9 DICKEY, D.A. \& FULLER, W.A (1979) "Distributions of the estimators for autoregressive time series with a unit root", Journal of the American Statistical Association, 74: 427-431.

10 DICKEY, D.A. \& FULLER, W.A (1981) "Likelihood ratio statistics for autoregressive time series with a unit root", Econometrica, 49: 10571072. 
11 FASANO, U. \& WANG, Q. (2002) "Testing the relationship between government spending and revenue: Evidence from GCC countries", IMF Working Paper WP/02/201, Policy and Development Review Department, IMF: Washington.

12 FRIEDMAN, M. (1978) "The limitations of tax limitations", Policy Review, 5: 7-14

13 FRIEDMAN, M. (1982) Interview with Washington Times, $2^{\text {nd }}$ June.

14 GHYSELS, E.; LEE, H.S. \& NOH, J. (1994) "Testing for unit roots in seasonal time series: Some theoretical extensions and a Monte Carlo investigation", Journal of Econometrics, 62: 415442.

15 GRANGER, C.W.J. (1988) "Some recent developments in a concept of causality", Journal of Econometrics, 39: 199-211.

16 HYLLEBERG, S.; ENGLE, R.F.; GRANGER, C.W.J. \& YOO, B.S. (1990) "Seasonal integration and cointegration", Journal of Econometrics, 44: 215-238.

17 JOHANSEN, S. (1985) Likelihood Based Inference in Cointegrated Vector Autoregressive Models, Oxford University Press: Oxford.

18 JOHANSEN, S. (1988) "Statistical analysis of cointegration vectors", Journal of Economic Dynamics and Control, 12: 213-254.

19 JOULFAIAN, D. \& MOOKERJEE, R. (1991) "Dynamics and government revenue and expenditure in industrial countries", Applied Economics, 23: 1869-1944.

20 KWIATKOWSKI, D.; PHILLIPS, P.; SCHMIDT, P. \& SHIN, Y. (1992) "Testing the null hypothesis of stationality against the alternative of a unit root: how sure are we that economic time series have a unit root?", Journal of Econometrics, 54: 159-178.

21 LI, X. (2001) "Government revenue, government expenditure and temporal causality: Evidence from China", Applied Economics, 33: 485-497.

22 MANAGE, N. \& MARLOW, M. (1986) "The causal relationship between federal expenditure and receipts", Southern Economic Journal, 52: 617629.

23 MELTZER, A.H. \& RICHARD, S.F (1981) "A rational theory of the size of the government", Journal of Political Economy, 89: 914-927.

24 MUSGRAVE, R.A. (1966) "Principles of budget determination", In A.H. Cameron \& W. Henderson (eds.) Public Finance: Selected Readings, Random House: New York.

25 NARAYAN, P.K. (2005) "The government revenue and government expenditure nexus: Empirical evidence from nine Asian countries", Journal of Asian Economics, 15: 1203-1216.
26 NARAYAN, P.K, \& NARAYAN, S. (2006)

"Government revenue and government expenditure nexus: Evidence from developing countries", Applied Economics, 38: 285-291.

27 OWOYE, O. (1995) “The causal relationship between taxes and expenditures in the G-7 countries: Cointegration and error correction models", Applied Economics Letters, 2: 19-22.

28 PEACOCK, A.T. \& WISEMAN, J. (1961) The Growth of Public Expenditure in the United Kingdom, Princeton University Press for the National Bureau of Economic Research: Princeston, NJ.

29 RAM, R. (1988) "Additional evidence on causality between government revenue and government expenditure", Public Finance, 43: 261-269.

30 SHAR, A. \& BAFFES, J. (1994) "Causality and co-movement between taxes and expenditure: Historical evidence from Argentina, Brazil and Mexico", Journal of Development Economics, 44: 311-331.

31 SHIN, D.W. \& SO, B.S. (2000) "Gaussian tests for seasonal unit roots based on Cauchy estimation and recursive mean adjustments", Journal of Econometrics, 99: 107-137.

32 SOUTH AFRICAN RESERVE BANK Quarterly Bulletins (Various issues) www.reservebank.co.za.

33 VON FURSTENBERG, V.G.M.; GREEN, R.J. \& JEONG, R.H. (1986) "Tax and spend or spend and tax", Review of Economics and Statistics, 68: 179-188. 


\section{Appendix}

Appendix 1: Transformations on the model

$y_{1, t}=(1+\mathrm{L})\left(1+\mathrm{L}^{2}\right)\left(1+\mathrm{L}^{4}+\mathrm{L}^{8}\right) y_{t}$

$y_{2, t}=-(1-\mathrm{L})\left(1+\mathrm{L}^{2}\right)\left(1+\mathrm{L}^{4}+\mathrm{L}^{8}\right) y_{t}$

$y_{3, t}=-\left(1-\mathrm{L}^{2}\right)\left(1+\mathrm{L}^{4}+\mathrm{L}^{8}\right) y_{t}$

$y_{4, t}=-\left(1-\mathrm{L}^{4}\right)\left(1-\mathrm{L} \sqrt{3}+\mathrm{L}^{2}\right)\left(1+\mathrm{L}^{2}+\mathrm{L}^{4}\right) y_{t}$

$y_{5, t}=-\left(1-\mathrm{L}^{4}\right)\left(1+\mathrm{L} \sqrt{3}+\mathrm{L}^{2}\right)\left(1+\mathrm{L}^{2}+\mathrm{L}^{4}\right) y_{t}$

$y_{6, t}=-\left(1-\mathrm{L}^{4}\right)\left(1-\mathrm{L}^{2}+\mathrm{L}^{4}\right)\left(1-\mathrm{L}+\mathrm{L}^{2}\right) y_{t}$

$y_{7, t}=-\left(1-\mathrm{L}^{4}\right)\left(1-\mathrm{L}^{2}+\mathrm{L}^{4}\right)\left(1+\mathrm{L}+\mathrm{L}^{2}\right) y_{t}$

$y_{8, t}=\left(1-\mathrm{L}^{12}\right) y_{t}$

Table A1: Tests of seasonal unit root in monthly data

\begin{tabular}{|l|l|l|}
\hline \multicolumn{1}{|c|}{ Null hypothesis } & \multicolumn{1}{c|}{ Alternative hypothesis } & \multicolumn{1}{c|}{ Test statistic } \\
\hline$\pi_{1}=0$ & $\pi_{1}<0$ & $t\left(\pi_{1}\right)$ \\
\hline$\pi_{2}=0$ & $\pi_{1}<0$ & $t\left(\pi_{2}\right)$ \\
\hline$\pi_{3} \cap \pi_{4}=0$ & $\pi_{3} \cup \pi_{4} \neq 0$ & $F\left(\pi_{3}, \pi_{4}\right)$ \\
\hline$\pi_{5} \cap \pi_{6}=0$ & $\pi_{5} \cup \pi_{6} \neq 0$ & $F\left(\pi_{5}, \pi_{6}\right)$ \\
\hline$\pi_{7} \cap \pi_{8}=0$ & $\pi_{7} \cup \pi_{8} \neq 0$ & $F\left(\pi_{7}, \pi_{8}\right)$ \\
\hline$\pi_{9} \cap \pi_{10}=0$ & $\pi_{9} \cup \pi_{10} \neq 0$ & $F\left(\pi_{9}, \pi_{10}\right)$ \\
\hline$\pi_{11} \cap \pi_{12}=0$ & $\pi_{11} \cup \pi_{12} \neq 0$ & $F\left(\pi_{11}, \pi_{12}\right)$ \\
\hline$\pi_{2} \cap \ldots \ldots . \cap \pi_{12}=0$ & $\pi_{2} \cup \ldots . . \cup \pi_{12} \neq 0$ & $F\left(\pi_{2}, \ldots \ldots \pi_{12}\right)$ \\
\hline$\pi_{1} \cap \ldots \ldots . \cap \pi_{12}=0$ & $\pi_{1} \cup \ldots \ldots . . \cup \pi_{12} \neq 0$ & $F\left(\pi_{1} \ldots \ldots \pi_{12}\right)$ \\
\hline
\end{tabular}

